\title{
Political trust in Iceland: Performance or politics?
}

\author{
Sjöfn Vilhelmsdóttir, PhD student, Faculty of Political Science, University \\ of Iceland
}

Gunnar Helgi Kristinsson, Professor, Faculty of Political Science, University of Iceland

\begin{abstract}
Economic performance has a well-known relationship to political trust. If the economy is perceived as performing well, the levels of political trust are likely to improve. During the 2008 economic crash in Iceland, this relationship seemed vindicated once more. Political trust in Iceland fell from very high to medium levels. Paradoxically, strong indicators of good economic performance after the crash have not been reflected in similarly strong indicators of greater political trust. Thus, while the economy has recovered, political trust has not followed suit to a comparable degree. To account for this discrepancy, we analyse the data on political trust in Iceland before and after the crash. Our findings indicate that while the economy is important in generating political trust, improved economic performance does not account for the whole scenario. The political impact of the crisis remains an obstacle to re-establishing political trust to previous levels, as identifying with a party in the government fails to contribute to political trust in the previous manner. Similarly, personal experience of the crisis may have created a sense of alienation among age cohorts that were particularly affected by the crash and the subsequent economic recession.
\end{abstract}

Keywords: Political trust; government performance; party identification; financial crisis; economic crash; Iceland. 


\section{Introduction}

Countries that have experienced a major change in a short period of time provide interesting cases to study public attitudes towards the political system (Norris 2011). The 2008 financial meltdown and its vast impact on Icelandic society make Iceland an intriguing case for the study on political trust. Icelanders refer to the fall of the country's three largest banks in the beginning of October 2008 as the 'crash'. In the years leading up to the crash, Icelanders had been enjoying political stability and strong economic growth, placing the country on the top of the United Nations' Human Development Index in 2007 (United Nations Development Programme 2007). Economists refer to Iceland's financial and economic downturn in the last months of 2008 as the 'collapse of a country', describing the deepest and most rapid financial crisis of a country recorded in peacetime (Danielsson \& Zoega 2009). It caused a wide range of serious negative impacts, plunging the country into a severe economic recession and leading to social and political unrest in the following months and years (see, e.g., Bernburg 2016; Indriðason, Önnudóttir, Pórisdóttir \& Harðarson 2017; Ólafsson, Kristjánsson \& Stefánsson 2012a, 2012b). This disturbance found immediate expression in the 2009 election when the politicians those considered responsible for the crisis suffered heavily (Indriðason 2014). The dramatic developments following the crash also caused substantial changes in Icelanders' trust in political and public institutions. Gallup's annual public trust survey in February 2008 showed that $43 \%$ of the respondents reported 'a lot' or 'a great deal' of trust in the national parliament Alpingi and 40\% in the country's banking system. A year later, four months after the financial meltdown in the beginning of October 2008, only $13 \%$ of the respondents expressed trust in the parliament and a mere $4 \%$ in the banking system (Gallup n.d.). Evidence from other European countries that were most exposed to the financial crisis, such as Greece, Cyprus, Portugal, Spain and Ireland, showed a similar trend - a drastic decline in citizens' trust in national governmental institutions (see Armingeon \& Guthmann 2014; Roth, Nowak-Lehmann \& Otter 2011; van Erkel \& van der Meer 2016). The distinct impact of the financial crisis on political trust levels across Europe support the claim that economic performance can be regarded as a key source of political trust. Nonetheless, through a combination of luck and effort, Iceland's economic system not only survived the crash but actually entered a phase of rapid expansion with economic growth and full employment. In 2017, nine years after the crash, Icelanders enjoyed economic conditions, in terms of gross domestic product per capita, that were better than pre-crisis levels (OECD 2017). However, in Gallup's (n.d.) annual trust survey that year, only $22 \%$ of the respondents expressed trust in the parliament, still far off from pre-crash trust levels. Thus, even if negative evaluations of policy performance appear to have brought on lower levels of confidence in the parliament, the post-crisis boom has so far been insufficient in restoring trust to its former levels.

Lower levels of political trust in Iceland after the 2008 economic crash have been at the centre of public debate. The crash was followed by increasing electoral volatility, party system fragmentation and a much weaker coalition governments than had 
prevailed since the early 1990s. While the economy started to show signs of recovery by 2011, followed by a strong economic growth (Statistics Iceland n.d.), political instability remained a problem. To radical reformers, lower levels of political trust indicate the need for far-reaching constitutional reforms, while to incremental reformers, such levels underline the need for a return to normal politics and political stability. Successive governments after the crash have pointed to the continuously improving economic condition as an indicator of their trustworthiness, but voters do not appear to be in a trusting mood regarding political representation. The crash was followed by calls for several representative reforms, which would have reduced the role of the conventional parliamentary party government and instigated greater measures for personalised voting, a stronger role for the president, a more active parliament and direct democracy. Some of these demands found expression in a failed constitutional bill, which to some extent, remains at the centre of the controversy concerning representative reforms. Adherents of representative reforms perceive them as the keys to greater confidence. Critics view them as potential threats to a stable government.

In this paper, our task is to unravel the apparent paradox of political trust in Iceland. Specifically, while the economic crash was clearly instrumental in undermining trust, the economic recovery has not brought with it a corresponding return to previous levels of trust. After discussing the relevance and the conceptualisation of political trust, we develop theoretical expectations concerning the probable influencing factors. To address the trust issues in Iceland, we develop expectations on the basis of two important research traditions. On one hand, political trust is produced by strong policy performance, for example, regarding the economy. On the other hand, political trust is generated by attachment to and identification with important political actors, such as political parties. From this perspective, identification with a political party in the parliamentary majority should enhance political trust. We then analyse the European Social Survey (ESS) data from three points in time, prior to the crash (2004), a few years after the crash (2012) and after the economic recovery (2016), to test our expectations.

\section{The concept of political trust}

Political trust is closely related to other positive terms that are used to describe citizens' orientations towards their political system, such as support, political allegiance, commitment and legitimacy (Citrin \& Muste 1993). Its opposites that belong to the same family of concepts include political alienation, disaffection and estrangement. The implication is that greater popular trust and support enable governments to function more effectively. Listhaug and Ringdal (2008) emphasise the positive relationship between high levels of political trust and economic and social development. In fact, they regard high levels of political trust, such as in the Nordic countries, "as a success criterion for societies" (p. 131).

While the literature suggests that political trust is a key element in the workings of democracy, the notion of political trust remains contested (Hooghe \& Zmerli 2011). Newton (2008) notes that the concept of political trust "is a vague and slippery one, 
and theories and assumptions about it are tangled and complex" (p. 242). In the social science literature, trust is conceptualised as both a rational assessment and an affective feeling that has different implications for social inquiry (Coleman 1988; Fukuyama 1995; Hardin 2002; Maloy 2009; Offe 1999; Uslaner 2002). Scholars who conceptualise political trust as a rational notion focus on the perceived qualities of the trustees - the institutions and the actors in the political system. Political trust is generated when citizens perceive (according to their cognitive-based judgements) the political system as taking care of their interests, governing effectively and producing desirable outcomes (Citrin 1974; Hetherington 1998; Levi 2003; Miller \& Listhaug 1999; Newton 2008).

Scholars who conceptualise political trust as an affective feeling hold the view that another kind of trust is based on a moral commitment or a social norm to be trustworthy (Offe 1999; Putnam 1993, 2000). For this kind of trust, the inquiry on trust relations focuses on the truster, specifically on the characteristics of the person expressing trust. Here, trust is built through socialisation, resulting in affective feelings and identification with the institutions of the political system. According to Campbell et al. (1964), individuals develop partisan self-identities at an early age and tend to interpret information received later in life as reinforcements of earlier attachments. Almond and Verba (1989) likewise argue that political trust is generated through socialisation, where affective feelings towards the political system contribute to the creation of favourable conditions for democratic government. In their notion of civic culture, political attitudes, such as political trust, are enduring and stable traits of society and become part of the national culture. They are affective feelings, learned and transmitted through generations via socialisation, functioning as an attitudinal base for the existing political institutions. Rose and Mishler (2011) suggest that the culture-based notion of trust as an affective orientation and the institution-based idea of trust as an evaluative orientation should not necessarily be considered in conflict. Trust or distrust can be learned through early-life socialisation and relearned later in life based on actual experience in dealing with political institutions.

Whether trust is based on affective or evaluative considerations is not crucial for its measurement. It can be measured by using questionnaire items that estimate confidence in politicians and political institutions. Concretely, it means confidence that desired outcomes will occur through the agency of a political actor. It may be misplaced, misinformed or based entirely on affective factors. It may equally well be evaluative and based on cold calculations. Whatever the case, the trusting respondent will express confidence in political institutions and actors.

Scholars have referred to Easton's $(1965,1975)$ analytical description of system support to cater to citizens' orientation towards office holders, as well as detect the underlying institutional legitimacy of the political system. Easton makes an important distinction between diffuse and specific classes of political support when analysing overall support for the political system. Diffuse support represents citizens' perception that the political system's existence, principles and functioning reflect their own values and norms. Specific support signifies citizens' positive evaluation of the output performance 
of the political system, specifically the incumbent authorities. Moreover, citizens can have different sentiments towards various objects of political support; an individual may hold negative views of the political authorities while expressing confidence in the regime's institutions and support for its principles. The most extensive research projects on political trust have been undertaken in the context of Easton's notion of system support - conceptualising political trust as a multidimensional notion and analysing citizens' orientations towards different aspects of the political system as part of an overall assessment of system support (Dalton 2004; Norris 1999, 2011).

The Icelandic experience demonstrates the usefulness of making a distinction among different levels of trust and in various types of institutions. Kristinsson and Vilhelmsdóttir's (2015) review of political trust measures from 1984 to the 2008 financial crash showed that Iceland followed the Nordic trend, with high levels of support for democratic principles and confidence in core regime institutions, including the parliament, civil service, the justice system and the police (Table 1 shows the confidence levels). Hence, Iceland was one of the high-trusting countries, a term often used for the Nordic countries in cross-national studies (Klingemann 1999; Marien 2011a; Norris 2011).

Table 1. Confidence in the parliament, civil service, the justice system and the police in Iceland from a comparative perspective ${ }^{1}$

\begin{tabular}{|c|c|c|c|c|c|c|}
\hline & \multicolumn{4}{|c|}{ EVS waves } & \multirow{2}{*}{$\begin{array}{c}\text { Net } \\
\text { change }\end{array}$} & \multirow{2}{*}{$\begin{array}{c}\text { Net } \\
\text { change }\end{array}$} \\
\hline & 1 & 2 & 3 & 4 & & \\
\hline & $\begin{array}{l}1981- \\
1984\end{array}$ & 1990 & $\begin{array}{l}1999- \\
2000\end{array}$ & $\begin{array}{l}2008- \\
2010\end{array}$ & $\begin{array}{l}1981 / 1984- \\
2008 / 2010\end{array}$ & $\begin{array}{c}1999- \\
2008 / 2010\end{array}$ \\
\hline \multicolumn{7}{|l|}{ Confidence in parliament } \\
\hline Iceland & $56 \%$ & $54 \%$ & $72 \%$ & $40 \%$ & -16 & -33 \\
\hline Other Nordic countries: average & $52 \%$ & $46 \%$ & $47 \%$ & $60 \%$ & 8 & 13 \\
\hline EVS average & $48 \%$ & $43 \%$ & $36 \%$ & $40 \%$ & & \\
\hline \multicolumn{7}{|l|}{ Confidence in civil service } \\
\hline Iceland & $48 \%$ & $46 \%$ & $56 \%$ & $61 \%$ & 13 & 5 \\
\hline Other Nordic countries: average & $51 \%$ & $43 \%$ & $48 \%$ & $55 \%$ & 4 & 8 \\
\hline EVS average & $48 \%$ & $42 \%$ & $41 \%$ & $48 \%$ & & \\
\hline \multicolumn{7}{|l|}{ Confidence in the justice system } \\
\hline Iceland & $69 \%$ & $67 \%$ & $74 \%$ & $68 \%$ & -1 & -6 \\
\hline Other Nordic countries: average & $79 \%$ & $69 \%$ & $69 \%$ & $77 \%$ & -2 & 8 \\
\hline EVS average & $63 \%$ & $52 \%$ & $46 \%$ & $49 \%$ & & \\
\hline \multicolumn{7}{|l|}{ Confidence in the police } \\
\hline Iceland & $74 \%$ & $84 \%$ & $83 \%$ & $93 \%$ & 19 & 10 \\
\hline Other Nordic countries: average & $85 \%$ & $82 \%$ & $85 \%$ & $86 \%$ & 1 & 1 \\
\hline EVS average & $75 \%$ & $60 \%$ & $57 \%$ & $63 \%$ & & \\
\hline
\end{tabular}

Note. Questions: How much confidence do you have in civil service/ the justice system/ the police? Is it a great deal, quite a lot, not very much or none at all? Figure entries are the percentages of 'a great deal' and 'quite a lot'. Source: Four waves of EVS, 1981-2010. 
As presented in Table 1, the European Value Study (EVS) data collected in Iceland from 2009 to 2010 (9-15 months after the financial crash in October 2008) showed that the citizens continued to be highly trusting towards their civil service and the police, while exhibiting a stable and relatively high confidence in the justice system. In contrast, there was a sharp fall in public confidence in the parliament. The proportion of Icelanders who trusted the parliament 'a great deal' or 'quite a lot' decreased from a uniquely high $72 \%$ at the turn of the 21 st century to $40 \%$ in $2009-2010$, while trust in the other Nordic parliaments over the same period rose from $47 \%$ to $60 \%$. The Icelandic EVS data indicated two trends. First, the impact of the economic crash on political trust was concentrated on the representational side rather than the implementation side of the political system. This is in line with Önnudóttir and Hardarson's (2011) finding that the crash had a highly negative effect on Icelandic voters' satisfaction with how democracy worked. Second, as argued by Kristinsson and Vilhelmsdóttir (2015), the decline in political trust levels in Iceland following the crash should be viewed as a decrease in specific support rather than a legitimacy crisis. It seemed that the Icelandic public blamed the politicians for the crash and the ensuing economic hardship yet expressed confidence in regime institutions other than the parliament and strong diffuse support (to use Easton's terminology) for the political system.

Complementary findings emerged from other Icelandic studies on political trust in the aftermath of the 2008 crash. In 2013, the Institute of Social Science Research, University of Iceland conducted a study on public trust in the national parliament Alpingi, using survey and focus group methods. The study's findings were decisive; only $13 \%$ of the respondents expressed trust in Alpingi, while 60\% reported that they had rather little or very little trust in the national parliament. When asked for the reason(s) for their distrust, the majority of the participants replied that their distrust was directed towards the members of parliament (MPs) rather than the parliament itself. The participants believed that the MPs were not performing their work in accordance with the public's expectations regarding standards of behaviour in conducting parliamentary procedures and standards of efficiency in dealing with the severe problems facing the nation in the aftermath of the financial crash.

In his study on trust in crisis, Bjarnason (2014) used Gallup's 2012 survey data to examine public trust in four political and public institutions in Iceland: the national parliament, the police, the president/presidency and politicians. The study clearly demonstrated the growing gap in the levels of trust in different institutions in the post-2008 era. While the measured levels of trust in the police and the president were $85 \%$ and $53 \%$, respectively, only $11 \%$ of the respondents expressed trust in the parliament and $7 \%$ in politicians. Bjarnason identified different trends in political trust attitudes based on the respondents' socioeconomic backgrounds and political party affiliations. The respondents who expressed trust in the parliament tended to have higher educational attainment, were less likely to have experienced personal financial problems and reported support for the parties of the coalition government. In contrast, the respondents who expressed trust in the president were usually less educated, more often had personal 
financial problems and reported support for the opposition parties in the parliament.

From a broad perspective, we expect trust to be influenced by relatively objective factors associated with government performance and/or more subjective predispositions that are likely to affect evaluations of the government and its performance. Objective factors include the government's success in promoting economic growth or preventing unemployment but may be biased by personal experience and expectations as well. Subjective predispositions comprise the values, norms and identities that affect people's propensity to trust, to some extent irrespective of the government's actual performance. The two factors - performance and predispositions - are not mutually exclusive accounts of political trust. Indeed, they may be mutually reinforcing but are not the same, as discussed in the next section.

\section{Government performance and political trust}

The literature and empirical research on political trust have always emphasised the role of government performance in generating political trust and support (Bok 1997; Citrin 1974; Easton 1965; Miller \& Listhaug 1999; Polavieja 2013; van Erkel \& van der Meer 2016). Since the Second World War, governments have been assumed responsibility for the performance of their economies. As Listhaug and Wiberg (1995) point out, with the expansion of governments' economic role across public institutions, "it is likely that mass support for public institutions-parliament included-becomes increasingly sensitive to performance evaluations" (p. 301). In countries with an extensive public welfare system, public access to healthcare services, education and social security can also be considered government performance indicators (Kumlin 2011). Nonetheless, economic performance is a key variable explaining trust in the government (Lawrence 1997). The economic performance indicators include a country's gross national income and economic growth, as well as inflation and unemployment rates.

However, empirical evidence for the relationship between macroeconomic conditions and political trust has been mixed, especially when analysing long-term trends (Bok 1997; Dalton 2004, van der Meer \& Dekker 2011; van Erkel \& van der Meer 2016). Dalton (2004) notes that the long decline in political trust and support in many advanced industrial countries over the last few decades does not match their economic performance. Nye (1997) explains that there is some ambiguity regarding the link between measures of performance and measures of public trust in the government. First, when citizens express dissatisfaction with their government's performance, it raises the following questions: What is performance compared with? Is it compared with citizens' expectations? Is it compared with the government's past performance or with those of other nations? Van der Meer (2017) points out that the inconsistency in the effect of actual macroeconomic performance on political trust may be due to the methodological set-up of trust research. The most prominent studies on political trust are based on a cross-national comparison using survey data, where cross-national differences in trust are explained by cross-national differences in government performance. This set-up "assumes that people base their trust in politics on a direct or indirect comparison to 
the economic performance of other countries" (p. 279). Van der Meer (2017) suggests that a longitudinal comparison rather than a cross-national one would be more useful to test the effect of macroeconomic performance. The reason is that survey respondents are more likely to base their assessments of current economic performance on the past experience of their own country rather than the performance of other countries. Focusing on within-country longitudinal changes in economic performance in 15 European Union countries, van Erkel and van der Meer (2016) find that macroeconomic performance has an impact on political trust levels.

The relationship between macroeconomic performance and political trust may thus be more indirect and often mediated at the micro-level through citizens' perceptions of the economic circumstances. In their cross-national study on objective and subjective determinants of political trust, van der Meer and Dekker (2011) show that subjective perceptions of economic performance are the strongest determinants of political trust, while the contextual effect of economic development (the actual performance) has no significant impact on the trust variable. Studies based on American and European data show that the relationship between trust and prospective perceptions of the national economy is much stronger than between trust and the economic situation of an individual's own family (Bok 1997; Dalton 2004). These findings suggest that citizens hold their government more accountable for the national economy than their personal finances. A similar trend has been observed in Europe during the period of economic recession and austerity measures following the 2008 financial crisis (Armingeon \& Guthmann 2014; Polavieja 2013). In his study comparing survey responses in 2004 (pre-crisis) and in 2010 across 19 European countries, Polavieja (2013) observes a parallel trend between decreasing levels of political trust and increasing average levels of dissatisfaction with the economic situations of the countries. His findings suggest that not only citizens who have been directly harmed by the deteriorating economic conditions have become less trusting towards their government but also those who have not directly experienced economic hardship.

Based on these results, we should expect the state of the economy to be an important predictor of how political trust has developed in Iceland. Personal experience is not a necessary condition for positive general evaluations but may bolster their effects.

\section{Predispositions and political trust}

In representative democracies, parties and elections create a linkage between citizens and elites, and political trust levels are believed to provide an indication of the quality of this linkage (Marien 2011b). The political trust literature and empirical research indicate that citizens who support the parties forming the majority in the government (the 'winners') express more political trust than those identifying with the parties comprising the minority in the parliament (the 'losers') (Anderson \& Tverdova 2001; Dalton 2004; Holmberg 1999). Thus, when the political parties forming the government enjoy a large and solid support base, it is believed to have an enhancing effect on political trust. Elections in a representative democracy are about choosing among candidates to represent 
the voters' interest in political decision making; the structures of democratic elections are designed to produce winners and losers in elections. As Listhaug and Ringdal (2008) note, it is 'quite normal' for citizens who vote for the parties that lose elections to become less trusting towards the political system. Holmberg (1999) calls this effect of elections on political trust the 'home-team hypothesis', referring to how voters sympathise with the political party/parties in the government if they vote for any of them or identify with them.

One of the mechanisms affecting this relationship may be different policy preferences (Miller 1974; Miller \& Listhaug 1998). According to this view, political distrust and cynicism develop among citizens who prefer policy positions that differ from those implemented by the government/political parties in power. Similarly, when the political agenda expands and/or becomes fragmented, it becomes difficult, if not impossible, for the government to maximise voter satisfaction, creating volatility in electoral politics and causing more public dissatisfaction with the political process (Dalton 2004). Dalton points out that this development has occurred in advanced industrial democracies over the past several decades; we have observed the emergence of policy preferences across multiple-issue dimensions with new concerns, such as environmental quality, gender and minority rights, and cultural issues. The governments in these countries are asked to perform more functions than before, creating policy fragmentation. Dalton (2004) calls it a 'multidimensional policy space', which has led to a situation where the "government can satisfy most people some of the time, or some people most of the time, but not most of the people most of the time" (p. 146). Dalton's conclusion is that the expansion of policy goals and the complexity of the policy space have created new volatility in electoral politics and caused more public dissatisfaction with the political process, resulting in a gradual erosion of political support and trust in many advanced industrial democracies.

Hence, we expect political trust in Iceland to be strongly associated with support for parties in the government prior to the crash. Party identification was strong, as were the majorities behind the coalition government. In the subsequent period, there is greater room for doubt. As explained in the next section, the linkage function of the political parties was in some ways weakened as a consequence of the crash, with weaker party identification, vulnerable governments, a more fragmented party system and greater multidimensionality of the political system. After the crash, support for the parties in the government is therefore less likely than before to contribute to political trust.

\section{The context of political trust in Iceland}

Before analysing the relationship with individual-level data, we can establish that a rough correspondence seems to exist between macro-level indicators and levels of political trust over time. Over time, the level of political trust has been closely associated with economic performance. 


\section{STJÓRNSÝSLA}

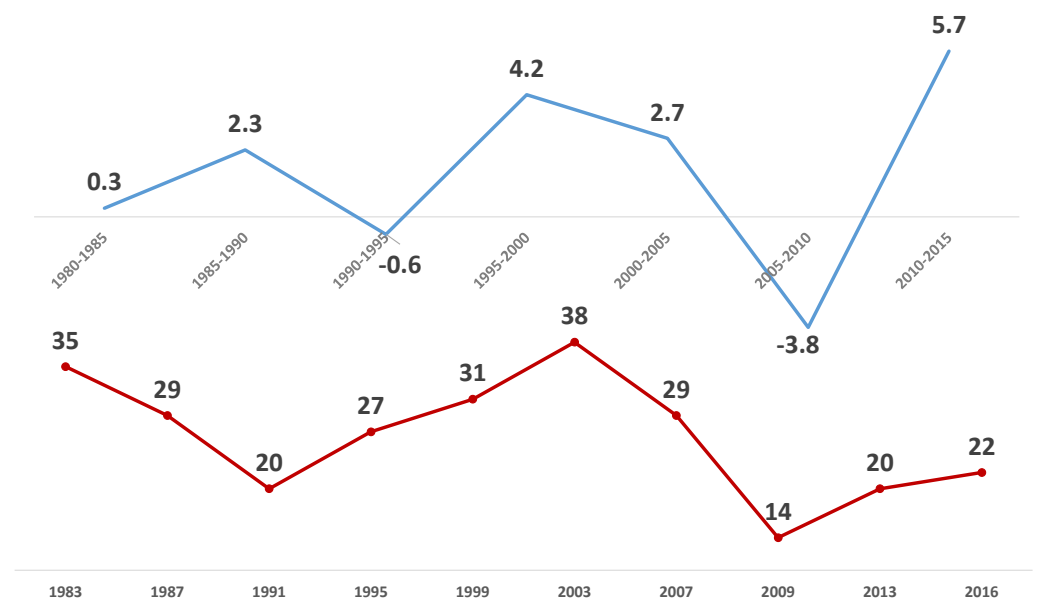

Figure 1. Trust in politicans 1983-2016 and gross national income per capita growth (five-year average \%) in Iceland 1980-2015

Notes. Question: Do you think that politicians are generally trustworthy, many of them are trustworthy, some are trustworthy, few or none are or is trustworthy? Figure entries are the percentages of 'generally trustworthy' and 'many of them are trustworthy'. Sources: Icelandic National Election Study (ICENES), 1983-2016; Statistics Iceland (www.statice.is).

The data from the Icelandic National Election Study (ICENES) allows us to trace the trends in trust in Icelandic politicians over the 1983-2016 period. As Figure 1 indicates, there have been fluctuations. In 1983, 36\% of Icelandic citizens said that politicians were generally trustworthy, or at least, many of them were. This number dropped to $21 \%$ in 1991, started to rise and peaked in 2003 at $38 \%$, only to fall again and take a sharp downturn from 2007 to 2009 , when only $14 \%$ of the respondents expressed trust in politicians. By 2013, trust was on the rise again, and in 2016, 23\% expressed trust in politicians. Whereas trust in political actors tends to react easily to specific political events and short-term changes, no final conclusions should be drawn from the trends presented in Figure 1 without further analysis. Nevertheless, trust in politicians seems sensitive to the economic situation, as observed when comparing the two trend lines in Figure 1. Public trust in politicians remained fairly high during the relatively prosperous 1980s but suffered in the early 1990s when the country was hit by economic recession. With the growing economy, trust was restored during the 1990s and the 2000s but declined as a consequence of the 2008 crash. With the Icelandic economic recovery since 2010, public trust in politicians also increased between 2009 and 2016. However, the growing gap between economic performance and political trust indicates that other factors may play roles as well.

In a politically stable system, we should expect support for the parties in the government to be a major source of political trust. This seemed to have been the case in Iceland until the crash. The data from the four waves of the EVS allows us to trace the trends in confidence in the parliament and support for political parties over the 
1984-2009/2010 period. Figure 2 shows that citizens who support the political parties forming the coalition government generally express more confidence in the parliament than those who support the minority parties in the parliament. In the 1984 measure, that difference accounted for 19 percentage points, decreasing to 11 points in 1999 and increasing again to 14 points in the 2009-2010 measure.

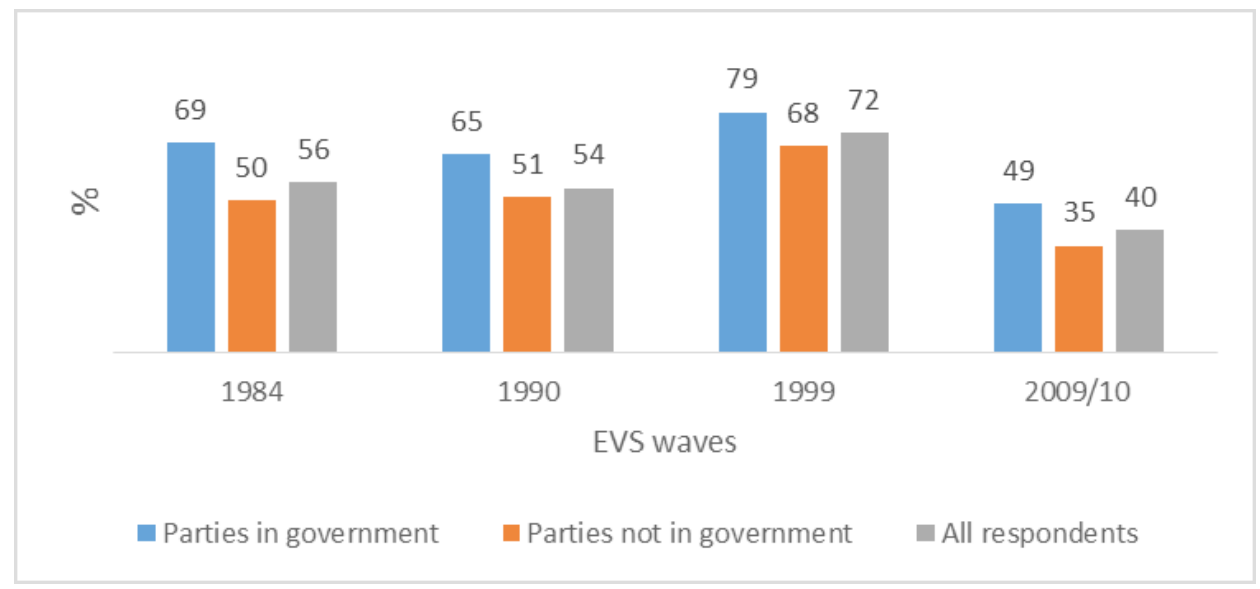

Figure 2. Percentage of respondents reporting confidence in parliament among supporters of parties forming the coalition government, supporters of minority parties in parliament and all respondents

Notes. Two questions: Q1. How much confidence do you have in the parliament? Is it 'a great deal', 'quite a lot', 'not very much' or 'none at all'? Figure entries are the percentages of 'a great deal' and 'quite a lot'. Q2. If there would be a general election tomorrow, which party would you vote for? Variable recoded to 'parties in the coalition government' and 'parties not in the coalition government' (at the time of the data collection). Sources: Four waves of European Values Study (EVS), 1984-2010 - Icelandic data.

The supporters of the parties in the parliamentary majority tend to have greater confidence in the parliament. The question is what happens to this source of political trust when the party system comes under pressure, which occurred in Iceland in the wake of the crash. If the supporters of the parties in the government no longer think that the government is in control or capable of channelling their preferences into public policy or policy results, this may undermine their trust. Whereas a relatively simple and stable party structure with strong majority coalitions contributed to political trust prior to the crash, post-crash politics fail to inspire trust in the same manner. The crash was followed by overcrowding of the political agenda, new issue dimensions dividing the government, an increasing number of political alternatives, weaker governing majorities and weaker party identification. Hence, we expect identification with parties in the government to have lost its power to increase political trust.

One of the effects of the crash was reduced identification with the main political parties and in particular, weaker identification with the parties in the government. At the same time, as shown by Indriðason et al. (2017), party identification became a much 
weaker predictor of party vote than before. The data from three rounds of the ESS allows us to trace the trends in citizens' identification with political parties in Iceland before and after the 2008 crash (see Figures 3 and 4).

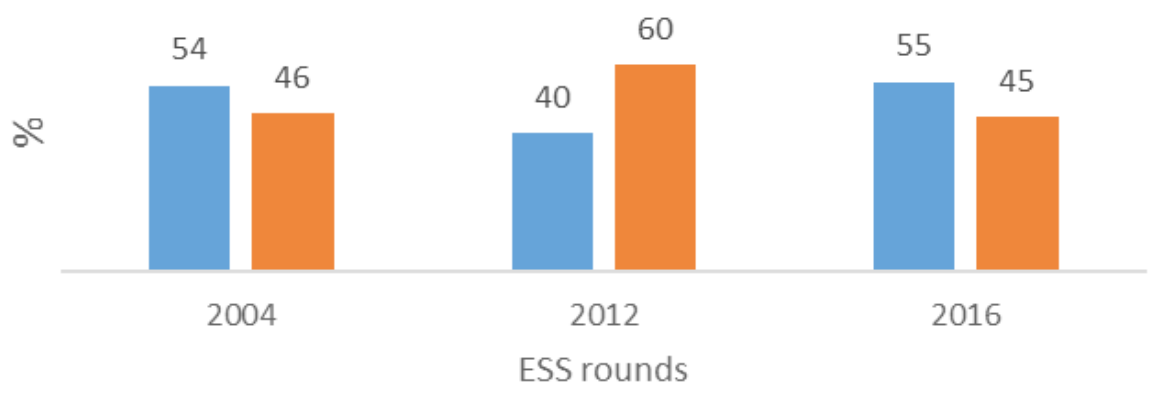

Feeling closer to a party

Not feeling closer to a party

Figure 3. Percentages of respondents who report feeling closer to a particular political party

Notes. Survey question: Is there a particular political party you feel closer to than all the other parties? (yes/no). Sources: Second, sixth and eighth rounds of European Social Survey (ESS) - Icelandic data.

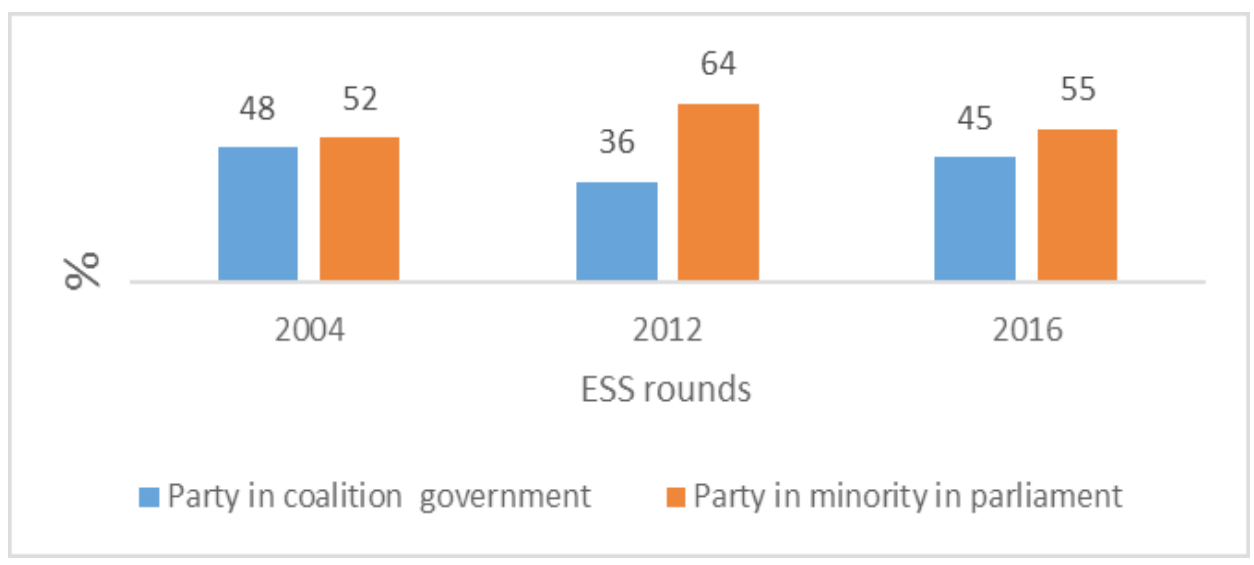

Figure 4. Percentages of respondents who report feeling close to a political party forming the coalition government vs. a minority party in or outside parliament

Notes. Figure entries are based on the survey question about 'which party you feel closer to' and then recoded as 'parties in the coalition government' and 'minority parties in or outside parliament' (at the time of the data collection). Sources: Second, sixth and eighth rounds of European Social Survey (ESS) - Icelandic data.

In 2004, 54\% of the respondents in the ESS survey reported feeling closer to one of the political parties than others. Of the respondents identifying with a particular political party, $48 \%$ did so with either of the two political parties forming the coalition 


\section{STJÓRNMÁL \& \\ STJÓRNSÝSLA}

government at that time: the Progressive Party (PP) or the Independence Party (IP). In 2012, these figures declined drastically; only $40 \%$ of the respondents felt close to a particular party, and merely $36 \%$ felt close to one of the two parties forming the coalition government at that time. This reflected the left-wing government's (2009-2013) failure to maintain its support base inside and outside the parliament. In fact, it had become a minority government during the last year of its term. Support among the voters had also declined, and in the 2013 parliamentary election, the government suffered the greatest electoral defeat in Icelandic political history, as the combined vote shares of the coalition partners dropped from $51.5 \%$ in 2009 to $23.8 \%$ in 2013 . This was not because the government was considered to have handled the crisis in an incompetent manner. The national election study in 2013 revealed that a convincing majority of the voters believed that the government had handled the crisis well (54\%), and only $23 \%$ thought that the opposition would have done a better job (ICENES 2013). The problem that the government encountered was partly the high level of expectations for which it was partly to blame, and partly the complications it encountered as a consequence of its own initiatives on several issues, which considerably complicated the political landscape. Thus, the coalition not only promised a Nordic welfare state in Iceland with emphasis on protecting the indebted homes but also started major initiatives concerning foreign policy, constitutional issues and administrative reforms, for which it lacked political support, time and policy-making resources to see through to completion. This undermined support for the governing parties and encouraged the emergence of a multitude of new parties since the main opposition parties, the IP and the PP, were too closely associated with the crash to be electable to a large group of voters. Thus, although the IP and the PP obtained a comfortable parliamentary majority in the 2013 election, the swing in the votes to them (from $38.5 \%$ in 2009 to $51.1 \%$ in 2013) was much smaller than the government's losses.

The crisis of the party system has been reflected in the increasing fractionalisation and multidimensionality of political alternatives, making it more difficult for the government and the opposition to structure political choices in a coherent manner. They have been either internally divided, weak in parliamentary support and exposed to political scandal issues, and/or short lived. Although party identification has to some extent been re-established since 2012, it is divided into more places and hence not the source of confidence in the government as previously. According to this view, the failure in the party system recovery since the 2008 crash is an important reason why confidence in politics has not been restored despite a rather successful economic performance. If political trust relies partly on the feeling that 'your people' are in charge, the failure to identify with the governing parties, as well as the governing parties' failure to signal in a non-ambivalent manner that they are in fact in charge, is likely to undermine confidence in politics and politicians.

Other factors may play a role as well, however. While perceptions of general economic performance have been shown to affect trust, personal experience may also exert an influence. Listhaug (1995) suggests that short-term shifts among different social 
groups can usually be explained by how specific government policies or election outcomes affect particular social groups, either favourably or unfavourably. Nonetheless, he points out that a continuing difference in trust levels among social groups suggests that the accumulation of political inequalities is alienating certain groups from the political process. A prime example of this kind of process is the difference in political trust levels in the United States between African Americans and whites, where African Americans have historically been underprivileged and politically marginalised. In the Icelandic case, different age cohorts were differently affected by the crash. The 20-49 age group experienced the greatest difficulties, particularly the 30-39 segment (Ólafsson et al. 2012b). In our analysis, we use age as a proxy for personal experience of the crash. Other background variables that need to be controlled for include education and gender (Marien 2008; Mayne \& Hakhverdian 2017). However, we start the analysis without strong expectations regarding the impact of education and gender.

\section{An integrated model}

Having made the case that performance and predispositions may contribute to political trust, we still lack a more integrated evaluation of how they may be related and how much each factor contributes at any given point in time. Ideally, either large-scale comparative data or longitudinal data should be used to put our ideas to the test. Since our focus is on Iceland, where longitudinal data is unavailable, we have to settle for less satisfactory solutions. In the following subsections, we attempt to evaluate how our dependent variable (political trust) has developed over time on the basis of a multivariate analysis, including perceived economic performance, party identification and key background variables.

\subsection{Data, measurements and descriptive statistics}

The data comes from the second, the sixth and the eighth rounds of the ESS in Iceland. The participants in the three rounds were chosen from a random probability sample, and all interviews were conducted face to face. The Social Science Research Institute, University of Iceland collected the data. The ESS 2004 data was collected from May to December 2005, the ESS 2012 data from October 2012 to March 2013 and the ESS 2016 data from November 2016 to June 2017. Table 2 shows further information on the sample of each round.

Table 2. Sample information

\begin{tabular}{lrrr}
\hline Sample items/rounds & ESS 2004 & ESS 2012 & ESS 2016 \\
\hline Sample size & 1,200 & 1,431 & 2,002 \\
Response rate \% & 51 & 57 & 46 \\
Male/female \% & $48 / 52$ & $50 / 50$ & $50 / 50$ \\
Age range: years & $15-90$ & $15-90$ & $15-94$ \\
Mean age: years & 44.5 & 44.1 & 48.2 \\
\hline
\end{tabular}




\subsection{The dependent variable}

The dependent variable is based on three measures of political trust in three ESS rounds: trust in 1) the country's parliament, 2) political parties and 3) politicians. The question on political trust was phrased as follows: 'Please tell me on the score of 0 to 10 how much you personally trust each of the institutions I read out. 0 means you don't trust an institution at all, and 10 means you have complete trust'. Figure 5 shows the mean scores for the three measures of political trust in the three ESS survey rounds.

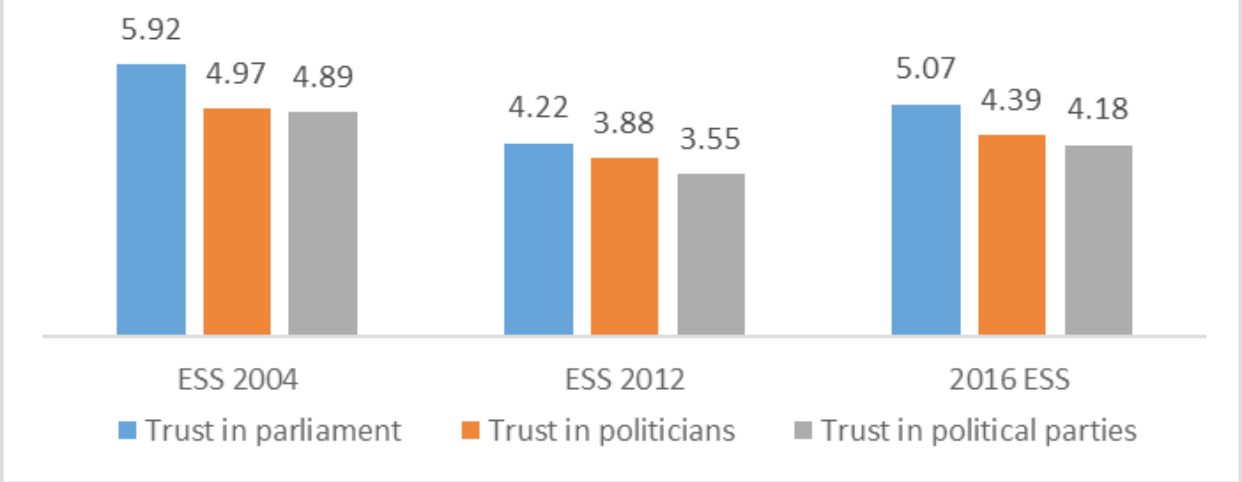

Figure 5. Trust in parliament, politicians and political parties - mean scores (0-10)

Further analysis showed a high correlation among the three questions, indicating that they all measured the latent construct. Cronbach's alpha values for the three items were 0.90, 0.91 and 0.91 for ESS 2004, ESS 2012 and ESS 2016, respectively. Consequently, an index was created as an additive summary of the three items, which ranged from 0 to 30 . Table 3 presents the mean scores for the political trust index in every ESS survey round.

\subsection{The independent variables}

The three ESS rounds did not have all the same questions in each wave; there were variations, depending on the focus theme of each round. Due to our interest in comparing the effects of perceived government performance and political party affiliation across the three time points, we could only use measures that were included in all three rounds, which limited our options for proxy variables.

Government performance. Political trust research has shown the important effect of subjective perceptions of economic performance on citizens' evaluations of institutional performance and their political trust (Bok 1997; van der Meer \& Dekker 2011). To measure government performance, we used the respondents' reported satisfaction with the state of the country's economy on an 11-point scale (from $0=$ extremely dissatisfied to $10=$ extremely satisfied). Table 3 shows the mean scores for the performance variable in every ESS survey round. 
Table 3. Descriptive statistics for the continuous variables: mean and standard deviation

\begin{tabular}{lrrr}
\hline & ESS 2004 & ESS 2012 & ESS 2016 \\
\hline Political trust index (0-30) & $15.76(5.92)$ & $11.58(6.20)$ & $13.63(6.02)$ \\
Satisfaction with economy (0-10) & $6.27(2.18)$ & $3.87(2.20)$ & $5.77(2.20)$ \\
Age & $44.5(17.8)$ & $44.1(18.7)$ & $48.3(18.1)$ \\
\hline
\end{tabular}

Party identification. The literature theorises about the effects of voting for the party/ parties in the government on political trust (Holmberg 1999), as well as the effects of identifying with the policies of the party/parties in the government (Miller 1974). We decided to use the measure of feeling closer to a particular party, rather than which party the respondents voted for in the last parliamentary elections. This was done to capture the respondents' orientations towards the political parties at the same time as they reported their political trust, since substantial time had passed since the last elections at the time of the data collection (e.g., 3.5-4 years in the case of ESS 2012). The question in the ESS questionnaires used was phrased as follows: "Is there a particular political party you feel closer to than all the other parties". The respondents could answer 'yes' or 'no'; those who replied affirmatively were then asked to name the political party to which they felt closer. We recoded each answer that cited a political party. The political parties that belonged to the coalition government (in the parliamentary majority) at the time of the data collection received code 1 . The cited political parties that were not part of the coalition government (in the parliamentary minority or not represented in the parliament) at the time of the data collection received code 0 . Table 4 shows the percentages of the respondents who reported feeling closer to parties in the coalition government and those feeling closer to parties in the parliamentary minority at the time of the data collection in each of the three ESS survey rounds.

Table 4. Descriptive statistics for the categorical variables: percentages of respondents

\begin{tabular}{lccc}
\hline & ESS 2004 & ESS 2012 & ESS 2016 \\
\hline Feeling close to a party in the coalition government & 24 & 13 & 22 \\
(Feeling close to a party in the parliamentary minority) & 26 & 24 & 29 \\
Gender: women & 52 & 50 & 50 \\
Education: university degree & 34 & 27 & 34 \\
\hline $\mathrm{N}$ & 579 & 752 & 878 \\
\hline
\end{tabular}

Additionally, we control for sociodemographic variables that have been shown to affect political trust. For the gender variable, women received code 1 , and men received code 0 . For the education variable, those holding a university degree received code 1 , and those who had not completed a university education received code 0 . The age variable took a range of numerical values - the respondents' ages. To examine if there was a curvilinear 
relationship between the age and the political trust variables, an age-squared variable was added. Finally, Table 5 shows the correlation between the dependent variable (the threeitem index on political trust) and all the independent variables.

Table 5. Correlation between the political trust index and the independent variables

\begin{tabular}{llrrr}
\hline & & ESS 2004 & ESS 2012 & ESS 2016 \\
\hline Gender (women) & Point-Biserial r & .01 & $.12 * *$ & $.09 * *$ \\
Age & $\mathrm{N}$ & 540 & 725 & 860 \\
& Pearson's r & -.01 & $-.14 * *$ & $-.07^{*}$ \\
Education (university degree) & $\mathrm{N}$ & 543 & 725 & 864 \\
& Point-Biserial r & .03 & $.12^{* *}$ & $.19 * * *$ \\
Satisfaction with state of economy & $\mathrm{N}$ & 481 & 723 & 855 \\
Feeling close to party in government & Pearson's r & $.35 * * *$ & $.49 * * *$ & $.52 * * *$ \\
\hline
\end{tabular}

Sign.: $\mathrm{p}<0.001^{* * *} ; \mathrm{p}<0.01^{* *} ; \mathrm{p}<0.05^{*}$

\section{Results}

Table 6 presents estimates from three sets of linear OLS regression models in the three ESS survey rounds. All coefficients in the regression table are standardised betas, allowing comparisons of the strength of the independent variables on the political trust variable in each survey round.

Table 6. Political trust, OLS regressions

\begin{tabular}{lccc}
\hline & ESS 2004 & ESS 2012 & ESS 2016 \\
\hline Gender - women & $.12^{\gamma}$ & $.16^{* *}$ & $.13^{* *}$ \\
Age & $.15^{*}$ & $-.77^{*}$ & $-.84^{* * *}$ \\
Age $^{2}$ & & $.77^{*}$ & $.84^{* * *}$ \\
Education - university degree & .03 & .08 & $.12^{* *}$ \\
Satisfaction with present state of economy & $.33^{* * *}$ & $.44^{* * *}$ & $.50^{* * *}$ \\
Feeling close to a party in government & $.29^{* * *}$ & .01 & $.08^{\vee}$ \\
Constant, sign. value & .000 & .000 & .000 \\
$\mathrm{R}^{2}$ adj. & .25 & .24 & .29 \\
\hline $\mathrm{N}$ & 224 & 260 & 421 \\
\hline
\end{tabular}

Notes. Dependent variable is political trust. Entries are standardised parameter estimates of a linear regression.

Sign.: $\mathrm{p}<0.001^{* * *} ; \mathrm{p}<0.01^{* *} ; \mathrm{p}<0.05^{*} ; \mathrm{p}<0.1^{\text {r. }}$. Sources: European Social Survey (ESS), second (2004), sixth (2012) and eighth (2016) rounds. 
In the 2004 survey round, 'satisfaction with the state of the economy' (government performance) and 'feeling closer to one of the parties in the government' (party identification) both have a strong positive effect on the political trust variable, 0.33 and 0.29 , respectively. In the 2012 round, the positive effect of the performance factor is stronger than in the 2004 measures, while the effect of identifying with the political parties in the government has become weak and is not statistically significant. In the 2016 survey, the positive impact of the economic performance factor has become stronger, up to 0.50. The effect of identifying with the political parties forming the coalition government shows some sign of rebounding yet remains relatively weak and only statistically significant at an alpha level of 0.1 . Thus, perceived government performance explains levels of political trust to a much greater extent in the two survey rounds conducted after the 2008 economic crash than previously. At the same time, citizens' identification with the political parties in the government as a source of public confidence in political institutions and actors has deteriorated. These results support both of our expectations. Evaluations of the state of the economy have a strong predictive value for levels of political trust, and identification with the parties in the government is strongly associated with political trust prior to the 2008 crash but not in the subsequent period.

The results also show that sociodemographic background matters in explaining the development of political trust in Iceland. Icelandic women express more trust in political institutions and actors than Icelandic men do for all the three time points, though the gender effect is only statistically significant at an alpha level of 0.1 in the ESS 2004 round. In the 2004 regression model, the relationship between age and political trust is linear; the older generations are more trusting than the younger ones, while education does not predict trust levels when controlling for other factors. Intriguingly, these relationships change in the post-crash rounds in 2012 and 2016, which indicate a strong curvilinear relationship between age and political trust. The youngest and the oldest respondents express greater political trust, while those between the ages of 40 and 60 report the lowest levels of political trust, according to the estimates. The impact of education on political trust is increasing and a significant predictor in the 2016 round; citizens who have completed a university degree are more trusting than those with lower levels of education.

\section{Discussion and conclusion}

The 2008 economic crash occurred in the wake of a rather unique period combining political stability and economic prosperity since the mid-1990s. The surprise and the severity of the crash set strong forces in motion, and political trust dwindled rapidly. Interestingly and in many respects, the post-crash debate focused more on the political aspects of what went wrong than on the economic ones, and the rapid recovery of the economy was not accompanied by a corresponding return to previous levels of political trust. Our study on the effects of the crash on political trust in Iceland indicates that several factors have an impact on how it develops. Searching for a simple formula for political trust may therefore not be fruitful. Strong performance may influence political 


\section{STJÓRNMÁL \& \\ STJÓRNSÝSLA}

trust in some cases but not in others. How performance interacts with other variables may be crucial.

Strong economic performance, accompanied with popular perceptions of it, had likely been an important factor contributing to high levels of political trust in the precrash period from the mid-1990s. However, rapid economic recovery after the crash shows that strong economic performance is not a sufficient condition for a return to similar levels of political trust. Our analysis points to other factors that may play a role. One is personal experience, represented by the age variable in our data. Among the age groups that are most severely affected by the crisis, we observe a slower return of political trust than among others, mostly the younger and the older cohorts. Thus, despite considerable efforts in improving their situation, the generation effect on trust largely corresponds to the age cohorts that are most severely weighed down by the debt crisis caused by the crash. For these groups, the crisis may have been a critical experience, creating a sense of alienation towards the political forces.

An even more important influence is the degree of political disruption accompanying the crash. Prior to the crash, identification with the parties in the government was an important source of confidence in the political system. The crash not only weakened the voters' identification with the established parties but had the additional effect of reducing the public feeling of confidence that politicians were in charge in the government. The crash was followed by an increasingly volatile political situation, characterised by multidimensionality and problems with creating or maintaining stable government coalitions. The analysis indicates that although the effects of identifying with a party in the government have increased to some extent after the crisis receded, they have by no means reached the pre-crash levels.

Other variables contribute to trust, including education. With the widening gap between system performance and trust in politicians, education has increasingly contributed to trust in politics. Higher levels of education may thus, to some extent, counterbalance the negative tone of the debate on politics and politicians. Similarly, gender plays a role; women are significantly more trusting of politicians compared with men. This difference may to some extent be related to increasingly higher educational levels among women, but even in an integrated model, gender continues to exert an influence. Therefore, the role of gender remains a subject for future research.

Based on our study, the key message to policy makers is that although political trust was damaged during the crash, it remained close to the European average, even at the height of the crisis, and has been restored to some degree since then. Trust in institutions other than the parliament, such as the civil service, the judiciary and the police, remains comparatively high. Although strong economic performance makes an important contribution to political trust, it appears insufficient on its own to bring about full recovery. Important features of party politics that contribute to political trust, such as party identification and support for political parties in the government, do not contribute to political trust in the manner that they did prior to the crash. Thus, forging a well-functioning party system and a stable government seems a major prerequisite for restoring political trust. 


\section{Note}

1 Four waves of EVS have been conducted in Denmark: in 1981, 1990, 1999 and 2008. Three waves of EVS has been conducted in Finland: in 1990, 2000 and 2009. Three waves of EVS have been conducted in Norway: in 1982, 1990 and 2008. Four waves of EVS have been conducted in Sweden: in 1982, 1990, 1999-2000 and 2009-2010. Source: wnw.europeanvaluesstudy.eu. It is to be noted that the EVS comparison has some shortcomings as the variation of participating countries increases in each successive wave: in terms of numbers countries, their geographic locations and their type of democracy and political history. The first EVS wave included only 15 countries and one region (Northern Ireland), and all of them fall under the category of well-established democracies of Western Europe and North America. In the second wave in 1990 many of the transition countries of Central and Eastern Europe came in and the third wave in 1999 to 2000 saw a further extension east and to the Balkan states. In the fourth wave, 2008-2010, 47 countries and one region (Northern Ireland) took part, from all parts of Europe as well as three countries from the Caucasus region. Thus, a comparison of the EVS average scores between sequential waves should be done with caution because the variation in the number and characteristics of the participating countries increases with each wave.

\section{References}

Almond, G.A., and Verba, S. (1989). The Civic Culture: Political Attitudes and Democracy in Five Nations. Newbury Park, CA: Sage Publications.

Anderson, C.J., and Tverdova, Y. V. (2001). "Winners, Losers, and Attitudes about Government in Contemporary Democracies", International Political Science Review 22(4), 321-338.

Armingeon, K., and Guthmann, K. (2014). "Democracy in Crisis? The Declining Support for National Democracy in European Countries, 2007-2011”, European Journal of Political Research 53(3), 423-442.

Bernburg, J.G. (2016). Economic Crisis and Mass Protest: The Pots and Pans Revolution in Iceland. Oxon: Routledge.

Bjarnason, T. (2014). “Traust í kreppu: Traust til Alpingis, lögreglu, stjórnmálamanna og forseta Íslands í kjölfar hrunsins”, Íslenska pjóðfélagið 5(2), 19-38.

Bok, D. (1997). "Measuring the Performance of Government", in J. Nye, S. Joseph, P.D. Zelikow, and D.C. King (eds.), Why People Don't Trust Government (pp. 55-76). Cambridge, MA: Harvard University Press.

Campbell, A., Philip, C., Warren, M., and Stokes, D. (1964). The American Voter: An Abridgement. New York: John Wiley \& Sons.

Citrin, J., (1974). "Comment: The Political Relevance of Trust in Government", The American Political Science Review 68(3), 973-988.

Citrin, J. and Muste, C. (1993). "Trust in Government", in J.P. Robinson, P.R. Shaver, and L.S. Wrightsman (eds.), Measures of Political Attitudes (pp. 465-532). San Diego, CA: Academic Press.

Coleman, J.S. (1988). "Social Capital in the Creation of Human Capital", The American Journal of Sociology 94, S95-S120.

Dalton, R.J. (2004). Democratic Challenges, Democratic Choices. Oxford: Oxford University Press.

Danielsson, J., and Zoega, G. (2009). The Collapse of a Country - 2nd ed. Institute of Economic Studies Working Paper Series, 2-29.

Easton, D. (1965). The Systems Analysis of Political Life. New York, NY: John Wiley \& Sons.

Easton, D. (1975). "A Re-assessment of the Concept of Political Support", British Journal of Political Science 5(4), 435-457.

Fukuyama, F. (1995). Trust: the Social Virtues and the Creation of Prosperity. New York, NY: Free Press.

Gallup (n.d.). "Traust til stofnana". Retrieved 03.01.2018 from https://www.gallup.is/nidurstodur/ traust-til-stofnana/

Hardin, R. (2002). Trust and Trustwortbiness. New York, NY: Russell Sage Foundation 
Hetherington, M.J. (1998). “The Political Relevance of Political Trust", American Political Science Review, 92(4), 791-808.

Hetherington, M.J. (2005). Why Trust Matters: Declining Political Trust and the Demise of American Liberalism. Princeton, NJ: Princeton University Press.

Holmberg, S. (1999). "Down and Down We Go: Political Trust in Sweden", in P. Norris (ed.), Critical Citizens: Global Support for Democratic Governance (pp. 103-122). Oxford: Oxford University Press.

Hooghe, M., and Zmerli, S. (2011). "Introduction: the Context of Political Trust", in S. Zmerli and M. Hooghe (eds.), Political Trust: Why Context Matters (pp. 1-11). Colchester, UK: ECPR Press.

ICENES (2013). Icelandic National Election Study - ICENES. Available from the Social Science Research Institute, University of Iceland website: http://fel.hi.is/icelandic_national_election_study_ icenes

Indriðason, I.H. (2014). “The Collapse: Economic Considerations in Vote Choice in Iceland”, Journal of Elections, Public Opinion \& Parties 24(2) 134-159.

Indriðason, I.H., Önnudóttir, E.H., Dórisdóttir, H., and Harðarson, Ó.P. (2017). "Re-electing the Culprints of the Crisis? Elections in the Aftermath of a Ression", Scandinavian Political Studies 40(1), 28-56.

Institute of Social Science Research (2013). Traust til Alpingis. Reykjavik: Institute of Social Science Research, University of Iceland. Retrieved from http://fel.hi.is/traust_til_althingis_0

Klingemann, H.-D. (1999). "Mapping Political Support in the 1990s: A Global Analysis", in P. Norris (ed.), Critical Citizens: Global Support for Democratic Governance (pp. 31-56). Oxford: Oxford University Press.

Kristinsson, G.H., and Vilhelmsdóttir, S. (2015 May). Legitimacy and Democracy in Iceland: Before and after the Crash, paper presented at conference 'Workings of Democracy, Practices, Norms and Understanding,' University of Iceland, Reykjavík, 27 May 2015.

Kumlin, S. (2011). "Dissatisfied Democrats, Policy Feedback and European Welfare States, 1976-2001", in S. Zmerli and M. Hooghe (eds.), Political Trust: Why Context Matters (pp. 163-185). Colchester, UK: ECPR Press.

Lawrence, R.Z. (1997). "Is it Really the Economy, Stupid?", in J. S. Nye Jr., P. D. Zelikow, and D.C. King (eds.), Why People Don't Trust Government (pp. 111-132). Cambridge, MA: Harvard University Press.

Levi, M. (2003). "A State of Trust", in V. Braithwaite and M. Levi (eds.), Trust and Governance (pp. 77101). New York, NY: Russell Sage Foundation.

Listhaug, O. (1995). “The Dynamics of Trust in Politicians", in H.-D. Klingemann and D. Fuchs (eds.), Citizens and the State (pp. 261-297). Oxford: Oxford University Press.

Listhaug, O., and Ringdal, K. (2008). "Trust in Political Institutions”, in H. Ervasti, T. Fridberg, M. Hjerm, and K. Ringdal (eds.), Nordic Social Attitudes in a European Perspective (pp. 131-151). Cheltenham: Edward Elgar.

Listhaug, O., and Wiberg, M. (1995). "Confidence in Political and Private Institutions", in H.-D. Klingemann and D. Fuchs (eds.), Citizens and the State (pp. 298-322). Oxford: Oxford University Press.

Maloy, J. S. (2009). "Two Concepts of Trust", The Journal of Politics 71(2), 492-505.

Marien, S. (2008). Trends and Gender Differences in Political Participation and Political Trust. A Comparative Analysis. PartiRep Working Paper: http://www.partirep.eu/workingpaper/trends-and-gender-differences-political-participation-and-political-trust-comparative

Marien, S. (2011a). "Measuring Political Trust Across Time and Space", in S. Zemerli and M. Hooghe (eds.), Political Trust: Why Context Matters (pp. 13-45). Colchester, UK: ECPR Press.

Marien, S. (2011b). "The Effect of Electoral Outcomes on Political Trust. A Multi-level Analysis of 23 Countries", Electoral Studies 30(4), 712-726.

Mayne, Q., and Hakhverdian, A. (2017). "Education, Socialization, and Political Trust", in S. Zmerli and T.W.G. v.d. Meer (eds.), Handbook on Political Trust (pp. 270-284). Cheltenham, UK Edward Elgar Publishing. 
Miller, A., and Listhaug, O. (1998). "Policy Preferences and Political Distrust: A Comparison of Norway, Sweden and the United States", Scandinavian Political Studies 21(2), 161-187.

Miller, A., and Listhaug, O. (1999). "Political Performance and Institutional Trust", in P. Norris (ed.), Critical Citizens: Global Support for Democratic Governance (pp. 204-218). Oxford: Oxford University Press.

Miller, A.H. (1974). "Political Issues and Trust in Government: 1964-1970", American Political Science Review 68(3), 951-972.

Newton, K. (2008). "Trust and Politics", in D. Castiglione, J.W. van Deth, and G. Wolleb (eds.), The Handbook of Social Capital (pp. 241-272). Oxford: University Press.

Norris, P. (2011). Democratic Deficit: Critical Citizens Revisited. New York, NY: Cambridge University Press.

Norris, P. (ed.) (1999). Critical Citizens: Global Support for Democratic Governance. Oxford, UK: Oxford University Press.

Nye, J.S. (1997). "Introduction: The Decline of Confidence in Government", in J.S. Nye, P.D. Zelikow, and D.C. King (eds.), Why People Don't Trust Government (pp. 1-18). Cambridge, MA: Harvard University Press.

OECD (2017). OECD Economic Surveys: Iceland 2017. Paris: OECD Publishing http://dx.doi. org/10.1787/eco_surveys-isl-2017-en

Offe, C. (1999). "How Can We Trust Our Fellow Citizens?”, in M.E. Warren (ed.), Democracy and Trust (pp. 42-87). Cambridge: Cambridge University Press.

Ólafsson S, Kristjánsson, A.S., and Stefánsson, K. (2012a). Ábrif fjármálahrunsins á lifskjöor pjódarinnar Skýrsla I: Umfang kreppunnar og afkoma ólikera tekjubópa. Reykjavík: Djóðmálastofnun Háskóla Íslands. Available at: https://rafhladan.is/bitstream/handle/10802/8052/skyrsla_i-umfang_kreppunnar_ og-afkoma_olikra_tekjuhopa--lokautgafa.pdf?sequence=1

Ólafsson S, Kristjánsson, A.S., and Stefánsson, K. (2012b). Ábrif fjármálahrunsins á lifskjöör pjóöarinnar. Skýrsla II: Áhrif mótvagisaðgerða á skuldavanda, fátaket og atvinnu. Reykjavík: Djóðmálastofnun Háskóla Íslands. Available at: http://thjodmalastofnun.hi.is/sites/thjodmalastofnun.hi.is/files/skrar/ahrif_ motvaegisadgerda_a_skuldavanda_fataekt_og_atvinnu.pdf

Önnudóttir, E.H., and Harðarson, O.Th. (2011). "Policy Performance and Satisfaction with Democracy", Icelandic Review of Politics \& Administration 7(2), 411-429.

Polavieja, J. (2013). "Economic Crisis, Political Legitimacy, and Social Cohesion", in D. Gallie (ed.), Economic Crisis, Quality of Work and Social Integration: The European Experience (pp. 256-278). Oxford: Oxford University Press.

Putnam, R.D. (1993). Making Democracy Work: Civic Traditions of Modern Italy. Princeton, NJ: Princeton University Press.

Putnam, R.D. (2000). Bowling Alone: The Collapse and Revival of American Community. New York, NY: Simon $\&$ Schuster Paperbacks.

Rose, R., and Mishler, W. (2011). "Political Trust and Distrust in Post-authoritarian Contexts", in S. Zmerli and M. Hooghe (eds.), Political Trust: Why Context Matters (pp. 117-140). Colchester, UK: ECPR Press.

Roth, F., Nowak-Lehmann D.F., and Otter, T. (2011). Has the Financial Crisis Shattered Citizens' Trust in National and European Governmental Institutions? Evidence from the EU Member States, 1999-2010. CEPS Working Document.

Statistics Iceland (n.d.). "Gross domestic product - GDP growth 2007-2017”. Retrieved 10.05.2018 from https://www.statice.is/statistics/economy/national-accounts/gross-domestic-product/

Uslaner, E.M. (2002). The Moral Foundations of Trust. Cambridge, UK: Cambridge University Press.

United Nations Development Programme (2007). Human Development Report 2007/2008. New York, NY: Palgrave Macmillan. Available at: http://hdr.undp.org/en/content/human-development-report20078

van Erekl, P.F.A, and van der Meer, T.W.G. (2016). "Macroeconomic Performance, Political Trust and the Great Recession: A Multilevel Analysis of the Effects of Within-country Fluctuations in Mac- 
roeconomic Performance on Political Trust in 15 EU Countries, 1999-2011”, European Journal of Political Research 55(1), 177-197.

van der Meer, T., and Dekker, P. (2011). "Trustworthy States, Trusting Citizens? A Multilevel Study into Objective and Subjective Determinants of Political Trust", in S. Zmerli and M. Hooghe (eds.), Political Trust: Why Context Matters (pp. 95-116). Colchester, UK: ECPR Press.

van der Meer, T.W.G. (2017). "Democratic Input, Macroeconomic Output and Political Trust", in S. Zmerli and T.W.G. v. d. Meer (eds.), Handbook on Political Trust (pp. 270-284). Cheltenham, UK Edward Elgar Publishing. 
